\title{
HEDGES EXPRESSIONS IN CONFESSIONAL DISCOURSE OF IDA CRADDOCK'S SUICIDE NOTES
}

\author{
${ }^{a}$ Rizkya Fajarani Bahar, ${ }^{b}$ Lisetyo Ariyanti, S.S., M.Pd. \\ ${ }^{a, b}$ English Literature Program, Faculty of Languages and Arts, \\ State University of Surabaya \\ e-mail: lisetyoariyanti@unesa.ac.id
}

\begin{abstract}
Some people commited suicide tried to express what they felt and left message explaining the causes of why they committed suicide. The suicide note was written by the person who commited suicide as a purpose to give a sign to other people. One of those people was Ida Craddck who was a 19th century American. She advocated freedom of speech and women rights who committed suicide because of inappropriate decision from the judge. Her books were prosecuted by Anthony Comstock as obscene literature. This study was aimed to examine the hedges expressions that maintained the functions of confessional texts which were used by Craddock. The results found that hedges were used on her confessions to support her criticism and wish to the public. Those criticism and wish were confessed by Craddock to aware the public about people's freedom condition. Her confessions had function to tell her personal story that led her to suicide which could be learnt by other people so that they could have a better life. Finally, hedges were used to express her uncertainty of the truth of what she confessed about her cause of death.
\end{abstract}

Keywords: hedges expressions, the function of hedges expressions, confessional discourse, the function of confessional discourse, suicide note. 


\section{INTRODUCTION}

A fact about suicide phenomena nowadays makes people around the world need to pay more attention to other people. Suicide means ending your life. Data provided by the World Health Organization (WHO), over 800.000 people die due to suicide every year. This still can be increased in every year. There are some factors that lead them to commit suicide. Mental health, specifically depression is widely known as the most factors. Some of the suicide people try to express what they feel and what causes them commit suicide by leaving a message. The suicide note is written by the suicidal person by a purpose to give a sign to other people. Some of them tell about the reason why they commit suicide and some others show their feeling into it, for example, the apology to the family for committing suicide or say thank for all of the people who exist on their life. As suicide note is one of the ways they communicate to other people, it gives information to other people about the suicides' problems, feeling, and difficulties (Acinas, Robles, \& Peláez-Fernández, 2015).

There are many notable people who died because of commit suicide and left a suicide note, one of them is Ida Craddock. She was born in Philadelphia in 1857 and was a 19th century American advocate of freedom of speech and women's rights. She studied a tremendous amount of materials on such occult topics at the Theosophical Society. She wrote about sexuality that led her to conviction and imprisonment for obscenity. She also taught correspondence about the sacred nature of sex. Her books were phenomenal such as "Right Marital Living" and "The Wedding Night" that were prosecuted by Anthony Comstock as an obscene literature. Anthony Comstock prosecuted Ida under New York's anti-obscenity law in 1902. Due to this case, she finally committed suicide by inhaling illuminating gas to escape life in the prison and the asylum. Before her death, she wrote two letters that told people about her life journey that cause her suicide. They were delivered to her mother and public. She concluded the note to the public appeal to protect her written work so no one could protest her writing.

Suicide note is the way to deliver information about the suicides wants to say before committing suicide. Ida Craddock delivered her cause of death to many people by writing suicide notes so that it could influence the public's thought. Salager-Meyer (1997) in Miller (1997) defined that the use of hedges may appear more to a broad audiences that means Ida might express fuzziness by using hedges on her suicide notes. As Lakoff's claimed that women use more hedges than men (Engström, 2018). Hedges are the sense of vagueness that expresses uncertainty, possibilitiy and tentativeness of certain condition. It is used to doubts and suggests an opinion as given information (Coates, 2004).

Suicide notes provide direct information from the suicidal person and it is more accurate than that reported by other informant. Women tend to confess their feeling (S. Mills, 1997). Suicide note can be the way they express feeling and difficulties that cause them suicide. The confessional where they talk about the difficulties is used as the way they deal with the problems. Along with confessing their feeling, some possibilities that cause them suicide can be identified. The possibilities which are delivered by expressing doubt in telling their story can be expressed by using hedges. Due to this reason, this study is aimed to analyze the use of hedges expressions in Craddock's confessions through her suicide notes. The purpose of the study is to answer the research questions (1) what types and functions of hedges are used in the suicide notes? and (2) how are the hedges applied in the functions of confessional discourse? 


\section{LITERATURE REVIEW}

This part explains the definition of hedges expressions including its types and functions by Salager-Meyer (1997). The theory suggests seven types of hedges and four reasons for hedging. Also, the explanation of confessional discourse is presented. Mandziuk (2010) suggests three functions of confessional discourse that are used by women as the way they confess their feeling. The details of those explanations can be seen in the following parts.

\subsection{Hedges}

Hedges are linguistic resources that convey the fundamental characteristic of doubt and certainty (Mulatsih, 2008). Hedge as an important linguistic source or language phenomenon, what the users do during the procedure of hedges employment, obviously, is continuously making choice too. George Lakoff argues that hedges are words whose job is to make things fuzzier or less fuzzy (Lakoff, 1973). Lakoff discusses fuzzy logic on his article, to demonstrate that one has to throw one's hands in desperation when faced with vagueness and fuzziness problems. The use of hedges depends on the context of how it should be followed. The term hedges are simply a group of words that has a function to communicate. They modify the speakers in toning down their statement to reduce the risk of what people say depending on the communicative context (Murniati, 2013).

In the use of hedges expression, Salager-Meyer (1997) had done a study of hedges in written scientific discourse. She claimed that hedging was a human enterprise which means it is a resource found in many languages. She suggested that hedges were expressed in seven strategic stereotypes which can be seen as follows.

\subsubsection{Types of Hedges}

\section{a. Modal Auxiliary Verbs}

Modal auxiliary verbs are the most widely used by people to express uncertainty towards some things in written and spoken form. The most tentative modal are may, might, can, could, will, would, shall and should. The example of using the modal is:

- Such a measure might be more sensitive to change in health after specialist treatment.

\section{b. Modal Lexical Verbs}

It is also called speech act verbs because it is used to conveying doubt and evaluating rather than describing a thing. Some verbs of modal lexical verbs are to seem, to appear, to believe, to assume, to suggest, to estimate, to tend, to think, to argue, to indicate, to propose, and to speculate. The example of modal lexical verb is:

- Our analysis suggests that high doses of the drug can lead to relevant blood pressure reduction. 


\section{c. Adjectival, Adverbial and Nominal Phrases}

This type of hedges is classified into three forms, they are:

1) Probability adjectives: probable, possible, likely/unlikely

2) Nouns: claim, assumption, possibility, suggestion and estimate

3) Adverbs: apparently, perhaps, probably, possibly, likely, practically, presumably and virtually.

Those verbs can be found in the example below:

- Septicemia is likely to result, which might threaten his life.

\section{d. Approximators of Degree, Quantity, Frequency and Time}

This is used to deliver imprecision of quantity or probable measurement of something in particular. Some forms of this type include about, a lot of, approximately, generally, often, occasionally, roughly, usually, somewhat and somehow. The example can be seen as follow:

- Fever is present in about third of cases and sometimes there is neutropenia.

\section{e. Introductory Phrases}

This I used to express personal doubt of speakers or writers and direct involvement. Phrases such as I believe, it is our view that, to our knowledge, and we feel that are used for this type of hedges. The example is:

- We believe that the chronic fatigue syndrome reflects a complex interaction of several factors.

\section{f. If Clauses}

This expresses the possibility of certain condition. It means there is something to be fulfilled before something can be done. It is found through the use of phrases if anything, if true, if only, etc. the example can be seen as:

- If true, then, our study contradicts the myth that fishing attracts the bravest and strongest men.

\section{g. Compound Hedges}

This type is made up of several hedges such as modal auxiliary combines with lexical verb with a hedging content. For example, it would appear. It has double, triple or quadruple hedges such as it may suggest that, it seems reasonable to assume that, and it would seem somewhat unlikely that.

\subsection{Functions of Hedges}

\section{a. Minimize the "Threat-to-Face"}

Minimize the "threat-to-face" is the first function of hedges that lurks behind every act of communication. She claimed that it is the process where authors tone down their statements to reduce the opposition risk. This function is used when someone avoids humiliating other person or making them feels uncomfortable with his or her statement. 


\section{b. Ways of being More Precise in Reporting Result}

This function is used as one of the right ways to convey the goal of what a speaker or author says. It may represent the true state of the writer's understanding and may be used to negotiate an accurate representation of the state of the knowledge under discussion (Salager-Meyer, 1997).

\section{c. Politeness Strategies}

Politeness strategy is divided into two forms. The first is positive politeness strategy. It means that someone recognizes that someone else has a desire to be respected. On the other hand, negative politeness strategy is politeness which is used to show that someone expresses that they want to be respected. However, it is also assumed that someone is in some way imposing on them. This function of hedging is used when someone gives criticism or different opinion toward others. Its purpose is to make the hearer or the reader can wisely accept the critic disagreement.

\section{d. Established Writing Style}

This function is planned based on the needs of the purpose of the writing style. When a style of writing is not following the criteria by several journal types of research, this will not be noticed by them. This function can be concluded that the researcher who cites from a statement needs know what the value of the statement must be displayed.

A previous study found that the expressions of hedges could help the person to know other's feeling through a conversation (Saputra, n.d.). It focused on examining the types of hedges in pragmatic functions that hedges expressions provided the implicit meaning in Oprah Winfrey Talk Show. Unlike the previous study, this study focuses on examining the use of hedges in confessional discourse.

\subsubsection{Confessional Discourse}

The confessional form is sediment with specific meanings and functions to the operation of power and social control (Foucault, 1980). The confession fundamentally operates as a ritual of discourse that unfolds within a power relationship. It is someone's feelings, intentions, problems, desire and offenses that are hard to say (Alvarez, 2002). A person who confesses does so with knowledge of the evaluative response endemic to act. It has function in the discursive history to expose and exonerate, to evaluate and confirm. According to Mills (1997), confessional is the discourse that displays the operation of power most clearly. It is the way women talk about their problems and feelings to deal with it. A study about confessional discourse has been done by Mandziuk (2010) who claims that there are three functions of confessional discourse.

a. Confessional Discourse as Therapeutic

This function has a characteristic of giving self-realization to other women. It can suggest other women about how they should behave. This function also can be used to change the readers to have a better life.

b. Confessional Discourse as Didactic

Another function of confessional discourse is to express the experience to teach a lesson to other people. This function can be determined if the confessors confess their feeling or experience in which can change people through selfawareness by telling their circumstances and options. The confessors also can 
impart warning to other people about the society condition so that they can make a change within the society.

c. Confessional Discourse as Interrogatory

This function has a main concern about raising a question. The confessors raises question about the tradition or society condition. By asking question to the readers, they can let them think of the society condition. This function can also be used to control the people to have the same point of view with the confessor.

Confessional discourse was used in the presupposition in feminist speech (Nistiti \& Ariyanti, 2019). The study found that presupposition contributed to the functions of confessional discourse and formed a result into the main idea of power-sharing agreement. On the other hand, this study is aimed to know how hedges support the functions of confessional discourse.

\section{METHOD}

In order to analyze the data, descriptive qualitative method is used because this study does not deal with numerical and statistical data. Qualitative research is a research that focuses on people's perspective, experiences and how to make their sense of life which is reported in words (Litosseliti, 2010). It is used in this study because this study focuses in analyzing the content of the suicide notes which contain message or expressions towards the words. The descriptive qualitative method is used to analyze the confessions that contained hedges expressions that are used by Ida Craddock as her way to tell her cause of death trough the notes. Documentation is needed to analyze the data because the notes are in the form of documentation. The source of the data is taken from Ida Craddock suicide notes and the sentences of the notes that are considered as confession is taken to be examined. The notes were taken from a book of Collected Article of Ida Craddock published by Global Grey Publisher (Craddock, 2018). It was also uploaded on a website http://www.idacraddock.com/.

\section{RESULT AND DISCUSSION}

\subsection{Types and Functions of Hedges}

Salager-Meyer (1997) categorized hedges into seven types and four reasons of why people used hedges. The explanations about types and functions of hedges below were based on Salager-Meyer theory on Miller (1997).

\subsubsection{Types of Hedges}

This part explained the types of hedges that were found on Craddock's suicide notes. The theory by Salager-Meyer (1997) suggested seven taxonomies of hedges that were used on written scientific discourse however only five of them were used by Craddock to express her uncertainty while confessing her feeling on her suicide notes.

\section{a. Modal Auxiliary Verb}

The following sentences were the examples of modal auxiliary verbs that were used by Craddock on her suicide notes. 
(1) I am making this statement to the public because I wish to call attention to some of the salient features of Comstockism, in the hope that the public may be led to put down this growing menace to the liberties of the people.

(2) I fully expected that the public press of New York City would duly chronicle this most remarkable invasion of the rights of the people by such an abolishing of the trial by jury; but so far as I could learn, the press remained totally silent.

Modal auxiliary verb in the example (1) was the word may. It was used to express a possibility of certain condition. It supported her sentence which shown her wish to the public to be able to put down the growing menace of the people's liberty. This was used by Craddock to express her doubt whether her wish could be fulfilled or not.

Example (2) showed the use of modal auxiliary would. It was used to express the possibility of a certain condition or act in future time. It meant that the confessor uncertain about when the exact time of what they stated would happen. In this case, Craddock used it to show her expectation to the public press but doubt it at the same time about what they would do for her.

\section{b. Adjectival, Adverbial and Nominal Phrases}

The sentences below were the sentences used by Craddock that contained adjectival, adverbial and nominal phrases type.

(3) In that court, Judge MC Kean so far forgot his oath of office (to administer justice impartially) as to hotly denounce my book as "blasphemous" (presumably because I am teaching the duty and the joy of communion with God in the marriage relation so as to render it sacramental).

(4) When we reflect that Anthony Comstock has himself read perhaps more obscene books, and has gazed upon perhaps more lewd pictures than has any other one man in the United States, what are we to think of the probable state of Mr. Comstock's imagination today upon sexual matters?

Example (3) showed the use of word presumably which meant to be a possibility of the reason why the Judge criticized her books as blasphemous. Her claim on the example (3) expressed her uncertainty of the truth that happened to her.

Her uncertainty of the truth was also shown on the example (4). By using the word perhaps and probable, she expressed her doubt of what she had claimed about Comstock. Those words were used to show a possibility of what Comstock did such as read more obscene book, gazed upon lewd pictures and his imagination about sexual matters. However, those probabilities were delivered based on her opinion, so that hedges were used to tone down her ideas.

\section{c. Introductory Phrases}

The use of introductory phrase is shown on the example below.

(5) I believe that Mr. Comstock takes pleasure in lugging in all occasions a word picture (especially to a large audience) of the shocking possibilities of the corruption of the morals of innocent youth.

The phrase I believe on the example above was considered as plausibility shield in introductory phrases. It expressed uncertainty of the truth of what she had claimed and showed her opinion about Comstock. 


\section{d. If Clauses}

The examples (6) and (7) below showed the use of if clauses type of hedges.

(6) I have looked into the hearts of hundreds of men and women during the nine years in which I have been engaged in sex reform work, and my soul burns within me when I see how husbands and wives are suffering, and how nearly all of the suffering could be done away with, if only Anthony Comstock were not hoodwinking the public into believing that sexual information in printed books must be kept away from them, so as to protect the morals of innocent youth.

(7) Each time that I have been arrested, I have escaped by a compromise; but when I came to New York, that if again attacked by Comstockism, I would stand my ground and fight to the death.

If clauses were used on the example above. However, those phrases were used in different context. The example (6) showed the use of if only which had meaning as a wish of a condition that was possible to happen if another did not. Craddock showed her uncertainty of a condition when the youth moral could be protected from suffering in the household life if Comstock did not prohibit her writing from circulating in public.

On the other hand, example (7) showed two different conditions which were the probability of being attacked by Comstockism and the probability of what she would do. It also could be seen as a cause and effect of the probability of being attacked by Comstockism and as an effect she would decide to survive and fight to the death.

\section{e. Compound Hedges}

Compound hedges are also found on Craddock's note, as shown on the example below.

(8) Perhaps it may be that in my death more than in my life, the American people may be shocked into investigating the dreadful state of affairs which permits that unctuous sexual hypocrite, Anthony Comstock, to wax fat and arrogant, and to trample upon the liberties of the people, invading, in my own case, both my right to freedom of religion and to freedom of the press.

Example (8) showed the combination of adjectival, adverbial, and nominal phrases type and modal auxiliary verbs type. It was shown by the use of perhaps and may. Those phrases expressed strong fuzziness of Craddock's opinion about the American responses to the condition when people's liberty was trampled by Comstock. Since she did not know the exact truth of her claim, she used hedges to make it less strong to be an opinion.

\subsubsection{Functions of Hedges}

Table 4.1 Functions of Hedges

\begin{tabular}{|r|l|l|l|}
\hline \multicolumn{4}{|c|}{ Functions of Hedges on Craddock's Suicide Notes } \\
\hline No. & Functions of Hedges & \multicolumn{1}{|c|}{ Types of Hedges } & \multicolumn{1}{c|}{ Phrases } \\
\hline \multirow{2}{*}{1.} & $\begin{array}{l}\text { Minimize the "Threat- } \\
\text { to-Face" }\end{array}$ & $\begin{array}{l}\text { Adjectival, Adverbial and Nominal } \\
\text { Phrases }\end{array}$ & Presumably \\
\cline { 3 - 4 } & If Clauses & Perhaps \\
\hline \multirow{2}{*}{2.} & $\begin{array}{l}\text { Ways of being More } \\
\text { Precise in Reporting } \\
\text { Result }\end{array}$ & Modal Auxiliary Verbs & May \\
\cline { 3 - 4 } & Introductory Phrases & Would \\
\cline { 3 - 4 } & Politeness Strategy & Compound Hedges & Perhaps it may be that \\
\hline 3. & & & If Clauses \\
\hline
\end{tabular}


Table 4.1 showed the functions of hedges that were used by Craddock. Based on the types of hedges, the study found that those types categorized into three functions of hedges. The theory by Salager-Meyer (1997) suggested four functions of hedges on written scientific discourse. However, established writing style function was not found on Craddock's hedging expressions because she did not cite people's statement to tell her story.

\section{a. Minimize the "Threat-to-Face"}

The first function on hedges was to minimize the "threat-to-face". This function was used as a reason for avoiding humiliates other people and making the feel uncomfortable of what was claimed. Based on the data, phrases presumably, perhaps and the use of if clause were found as the reason why Craddock used hedges on her statements. The uses of phrases presumably and perhaps showed strong uncertainty of the truth of what she had claimed. By using those expressions, she tried to avoid humiliating other people especially Anthony Comstock, whom she delivered her criticism to, because her claims could affect the way people think of Comstock.

Her uncertainty about her statement was also found in using if clauses. It was used to minimize the threat toward the Comstockism. In other words, she avoided expressing an accusation of what Comstockism would do. Her fuzziness was expressed on her statement that she was uncertain whether the Comstockism would attack her or not.

\section{b. Ways of being More Precise in Reporting Result}

Another reason of why people used hedges was as the way of being more precise in reporting result. This function was used to represent the writer's understanding and to negotiate an accurate representation of the state. There were three types of hedges that used by Craddock on her notes that could be categorized to this function as displayed on the table 4.1.

Modal auxiliary verb may was used to watch out her statement since her notes were delivered to the public and avoided the impression of being constrain on delivering her wish. Also, the word would was used as the way she delivered her statement precisely since she was uncertain whether her wish could be fulfilled or not.

Another type of hedges, introductory phrase, was used to tone down her criticism towards Anthony Comstock so that her statement did not have bad impact on her since it was published. Her opinion was represented by using the phrase I believe which had function to tone down her criticism since it was based on her opinion.

A criticism was also delivered by using phrase perhaps it may be, categorized as compound hedges, which expressed strong fuzziness of what she claimed. Due to her notes were published and it could affect the public's opinion toward Comstock, she had to watch over her statement precisely by using hedges.

\section{c. Politeness Strategy}

The last function of hedges that was found on Craddock's notes was politeness strategy. Type of hedges if clause was used as negative politeness strategy. It was used to express her criticism toward Comstock that prohibited her writing to be circulating in public. It was categorized as negative politeness because she showed a disagreement of what Comstock did to her books and showed that she wanted to be respected to have a freedom of writing and living. 


\subsection{Functions of Confessional Discourse}

The explanations below were about the functions of confessions delivered by Craddock on her suicide notes. In addition, while confessing her feeling and difficulties, she used hedges to express her uncertainty of the truth of what she stated. The theory of Mandziuk (2010) was used to answer the research problem 2.

\section{a. Therapeutic Function}

Table 4.2 Types and Functions of Hedges in Therapeutic Function

\begin{tabular}{|l|l|}
\hline \multicolumn{1}{|c|}{ Confessional Discourse as Therapeutic } \\
\hline \multicolumn{1}{|c|}{ Types of Hedges } & \multicolumn{1}{|c|}{ Functions of Hedges } \\
\hline Modal Auxiliary Verbs & $\begin{array}{l}\text { Ways of being More Precise in Reporting } \\
\text { Result }\end{array}$ \\
\hline If Clauses & Politeness Strategy \\
\hline
\end{tabular}

Therapeutic function could help the confessors to deliver messages based on their point of view (Nistiti \& Ariyanti, 2019). In the use of confession, it gave solution for the readers' problems based on the confessor's experience. Through her confession on the note to the public, she delivered wishes to them that could aware them about people's liberty condition, as written on the example (1). Her confession told the truth of the condition that people did not realize. However, in delivering her wish to them, she used hedges may that represented her uncertainty whether her wish could be fulfilled or not. Hedges may had a function as to watch over her statement since her notes were delivered to the public and to avoid the impression of being forced on delivering her wish.

Mills (1997) suggested that the truth of the matter was less an issue than the effects of the discourse that could create many truths. The truth of the threatened of people's liberty as Craddock stated on the notes might bring new point of views to the readers. She confessed her desire to get a freedom of writing so that she could help the young people from household violent. While confessing her feeling, she used hedges to show her disagreement of Comstock decision that prohibited her books being published. Hedges if clause was used to show a possible condition when she could help young people from household violence if Comstock did not prosecuted her books.

In conclusion, hedges were used on her confessions to support her statements to the public. Those statements could give realization and aware the public about a possible condition that might be happen if another did not.

\section{b. Didactic Function}

Table 4.2 Types and Functions of Hedges in Didactic Function

\begin{tabular}{|l|l|}
\hline \multicolumn{1}{|c|}{ Types of Hedges } & \multicolumn{1}{|c|}{ Functions of Hedges } \\
\hline \multicolumn{1}{|c|}{ If Clauses } & Minimize the "Threat-to-Face" \\
\hline Modal Auxiliary Verbs & $\begin{array}{l}\text { Ways of being More Precise in Reporting } \\
\text { Result }\end{array}$ \\
\hline Introductory Phrases & \\
\hline Compound Hedges &
\end{tabular}

The confessor could be a mediator between the readers and their life experience. Confession, in this function, could be the way the confessors gave a lesson to the 
readers based on their experience. Thus, it could suggest the readers about proper behavior by telling them the circumstances and options through the confession. Hedges if clause on her statement, on example (7), was used to describe two conditions that happened as a cause and effect. Through her confession, she suggested the readers to be able to struggle for every condition. Moreover, it had function to avoid expressing an accusation of what the Comstockism would do.

Craddock had experienced unfairness in getting her freedom of living. Based on her experiences that she wrote on her suicide notes, she suggested other people to make a change of the society by delivering her wish. However, while delivering her wish, she used hedges expression to be more precise in representing it. Hedges type such as modal auxiliary verb was used to avoid constraining the public.

Confessional discourse as didactic was also used to impart a warning to other people. Craddock warned the public about the threatened of people's liberty by Comstock by criticized him. Along with her criticism to Comstock, the public could be more aware about the condition of the society. Furthermore, her criticisms were delivered by using hedges expressions to tone down her opinion so that it did not bring bad impact to her since it could affect people's point of view toward Comstock. Types of hedges such as introductory phrases and compound hedges were found on her suicide notes to support her criticisms toward Comstock.

\section{c. Interrogatory Function}

Table 4.2 Types and Functions of Hedges in Interrogatory Function

\begin{tabular}{|c|c|}
\hline \multicolumn{2}{|c|}{ Confessional Discourse as Interrogatory } \\
\hline Types of Hedges & Functions of Hedges \\
\hline Adjectival, Adverbial and Nominal Phrases & Minimize the "Threat-to-Face" \\
\hline
\end{tabular}

Interrogatory function had a main concern about rising question on confession. The confessor raise questions about society condition that could let the readers think about it. Moreover, the confession could lead people's opinion of the society.

The way Craddock confessed her opinion about Comstock was found in the form of question. Her question affected the readers to think about the possibility of the truth of her statement. Since she was uncertain about her opinion, she used hedges as an evasiveness mitigation of certainty to the truth. An adjectival word such as probable, and adverbial word such as perhaps were used to show her fuzziness of the statement. However, her confession could influence the readers to have the same opinion about Comstock as hers.

\section{DISCUSSION}

\subsection{The Embodiment of hedges in the Confessional Discourse}

Generally the findings found that hedges supported in conveying criticism and Craddock's wish to the public. She used hedges to deliver her opinion, claim and statement that contained criticism to people who were related to her case such as Anthony Comstock. Hedges were also used in delivering her expectation and wish to the public to make them realize of the people's liberty condition.

Criticism was the expression of disapproval of someone or something because of their faults or mistakes (P.V \& U., 1989). It was the way people communicated and delivered their opinion toward others. Criticism was the way people delivered their understanding, values clarification and the reform of society that would guide a professional life (Cosmin-Constantin \& Claudia, 2015). On her notes, she criticized 
Anthony Comstock because he prosecuted her book as obscene literature. She used some hedges words such as I believe and perhaps to show her uncertainties because what she claimed were based on her opinion. She used hedges to express her opinion because hedges were used for mitigating a criticism or request and softening a stance or opinion (Saputra, n.d.). While confessing her opinion, she expressed uncertainty to avoid making people uncomfortable with her statement and to tone down her statement to make it less strong to be an opinion.

Besides criticized the related people, she also delivered her wish to the public. It was represented by using hedges such as would and may. Wishes were delivered to namely opinion mining by revealing what people explicitly wanted to happen not what they liked or disliked (Goldberg et al., 2009). She addressed her wishes to the public to fulfill her expectation of what the public should do. However, the used of hedges words also showed her uncertainty whether her wish could be fulfilled or not. Her wishes that were confessed on her notes could aware the public to pay attention about the threatened of people's liberty and suggested them to fight for getting the justice for the public.

\subsection{Confessional Discourse to Support Telling Personal Story}

Women tended to confess their feeling and talked about their difficulties to deal with their problems by confessing their feeling (S. Mills, 1997). Along with confessing the problems and difficulties, the cause of death could be recognized by reading Ida Craddock's suicide notes. She shared her experiences of facing the demand and prosecution by Anthony Comstock because of her writing which was considered as obscene literature. However, by confessing her desire to get a freedom of living, she gave self-awareness to the readers that every woman had the rights to live freely. She also demanded her freedom of voice through her writing, freedom of religion and freedom of living as a free woman. Her inability to get her freedom finally led her to commit suicide.

Furthermore, the readers could learn about how she had struggle for her life through her confessions. She made the people aware of the people's liberty and warned them about the danger of Comstock that threatened people's liberty. She let the readers thought of the society condition and led their opinion to have the same point of view by raising question on her confessions. Those confessions were written by Ida Craddock at the moment before her death since suicide note could give information about what the suicides wanted to say on their last moment (Acinas et al., 2015). Ida Craddock's confessions on the notes were the way she shared to the public about her difficulties in facing the demand. By confessing her feeling, she delivered messages to the public so that they knew what caused her death. Those were the truth of what happened based on her personal story.

\section{CONCLUSION}

In conclusion, Ida Craddock used hedges expressions while confessing her feeling through the suicide notes. The confessions were delivered to tell her personal story about her cause of death. In addition, by using hedges she gave criticism to the people who were related to her case such as Anthony Comstock and delivered her wish to the public. Hedges were used to watch over her claims and opinions since the notes were delivered to the public, she avoided making people felt uncomfortable with her 
statements. Through her confessions, she gave self-realization and awareness to the public about people's liberty condition. The readers could learn based on her experiences so that they could make a change of the society. Also, she raised questions on her confession to let the public thought of the society's condition.

\section{SUGGESTION}

In order to analyze the data, descriptive qualitative method was used because this study did not deal with numerical and statistical data. Confessional discourse was an interesting scope of study. Due to this reason, there might be some others who were interested in viewing phenomena of confessional discourse. It was possible to use different object of the study or point of view in using the theory of confessional discourse. In addition, suicide note could also be used as an object of the study by using another point of view in the scope of discourse analysis.

\section{REFERENCES}

Acinas, M. P., Robles, J. I., \& Peláez-Fernández, M. Á. (2015). Suicide Note and the Psychological Autopsy: Associated Behavioral Aspects. Actas Esp Psiquiatr, 43(3), 69-79.

Alvarez, R. (2002). Confessions of an Information Worker: a Critical Analysis of Information Requirements Discourse. Information and Organization, 12, 85107.

Coates, J. (2004). Jennifer Coates : Differing Approaches to Language and Gender, $2-$ 3.

Cosmin-Constantin, B., \& Claudia, C. E. (2015). Rhetorical Critic's Role and Mission in Communication. Procedia - Social and Behavioral Sciences, 197(January 2016), 167-174. https://doi.org/10.1016/j.sbspro.2015.07.078

Craddock, I. (2018). The Collected Articles of Ida Craddock. Global Grey E-Books.

Engström, A. (2018). I' m Sure Women Use More Hedges, I think. University of Gavle.

Foucault, M. (1980). The History of Sexuality. Foucault's "History of Sexuality Volume I, The Will to Knowledge" (Vol. I).

Goldberg, A. B., Fillmore, N., Andrzejewski, D., Xu, Z., Gibson, B., \& Zhu, X. (2009). May all your wishes come true: A study of wishes and how to recognize them. NAACL HLT 2009 - Human Language Technologies: The 2009 Annual Conference of the North American Chapter of the Association for Computational Linguistics, Proceedings of the Conference, 263-271.

Lakoff, G. (1973). Hedges: A Study in Meaning Criteria and the Logic of Fuzzy Concepts. 2(4), 227.

Litosseliti, L. (2010). Research Methods in Linguistics.

Mandziuk, R. M. (2010). Confessional Discourse and Modern Desires: Power and Please in True Story Magazine, 18(9 November 2010), 37-41. https://doi.org/10.1080/07393180128076 
Miller, Tom, E. (1997). Functional Approaches t. Functional Approaches to Written Text: Classroom Applications.

Mills, R. (1997). The confession as a 'practice of freedom' : feminism, Foucault and elswhere thruts, 2 .

Mills, S. (1997). Discourse: The New Critical Idioms. (J. Drakakis, Ed.). New York: Routledge.

Mulatsih, S. (2008). Hedges: The Expressions of Doubt and Certainty. 4(2), 73-81.

Murniati. (2013). Types and Functions of Hedges Used In “ J . K . Rowling' s Interview With Oprah Winfrey Show, 13.

Nistiti, N. U., \& Ariyanti, L. (2019). Maintaining Confessional Discourse through Presupposition in Feminist Speech, 380(SoSHEC), 161-165.

P.V, S., \& U., M. (1989). How to handle criticism., 19(10), 317-321.

Salager-Meyer, F. (1997). I Think That Perhaps You Should: A Study of Hedges in Written Scientific Discourse. T. Miller (Ed.), Functional Approaches to Written Text: Classroom Applications, 105-118.

Saputra, H. M. (n.d.). The Fact of Hedges in Oprah Winfrey Talk Show. 